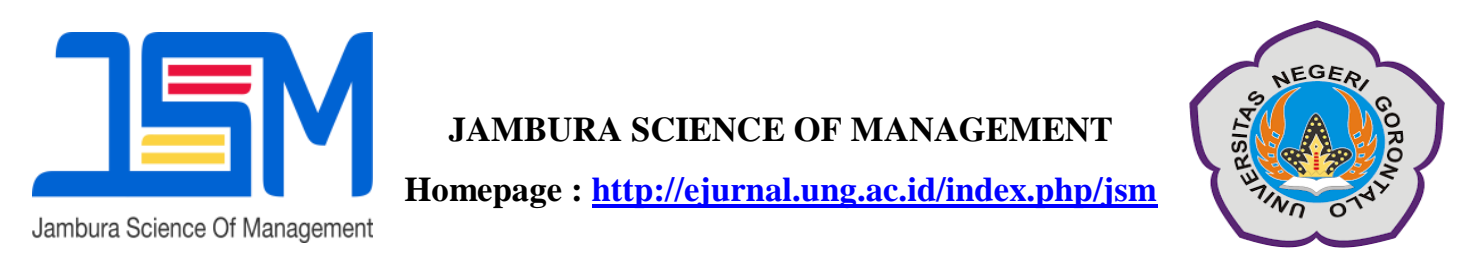

\title{
Effect of Employee Mutation on Job Stress in Gorontalo District Health Office
}

\author{
Pratiwi Biki \\ Department of Management, Faculty of Economics, Gorontalo State University \\ E-Mail :Pratiwi_Biki@gmail.com
}

\begin{abstract}
:
This study aims to examine and find out about how the influence of employee mutations on employee stress in the Gorontalo District Health Office. The population and sample used in this study were 74 people who were all employees at the Gorontalo District Health Office. Samples were chosen randomly and then the data obtained from the samples were analyzed using simple regression analysis techniques. The results of the analysis show that employee mutations have a significant positive effect on employee work stress. The contribution of the influence given by employee mutations to the ups and downs of employee stress is $34 \%$. While the remaining $66 \%$ is influenced by other factors that are not specifically explained in this study. These results indicate that if employee mutations are carried out in accordance with the principles of mutation, then the work stress experienced by employees can be minimized. However, the problem today is how the employee paradigm regarding the mutation itself. Mutations that should have been motivated turned out to be a scourge for employees who entered the list of mutations. Of course this is because the implementation of the mutations that have occurred so far have not referred to the HRM principles, where mutations are carried out in addition to fulfilling the shortage of staff in other units / sections as well as to place employees in accordance with their skills, abilities and fields. Current mutations are political products that are implemented and targeted at individuals who are not considered part of political promises. So, instead of minimizing stress, on the contrary it actually adds to work stress.
\end{abstract}

\section{Keywords: Employee mutation, performance}

In the organization and work environment, each individual will give a different attitude, depending on what they experience. Satisfaction in work occurs when what is expected by the workforce is fulfilled in reality, otherwise dissatisfaction occurs when the expectations of the workforce are not as expected and the problem will result in work stress. Job stress is basically a response to an individual's high pressure at work. This high pressure is often referred to as Stressor (Ernie and Kurniawan, 2005). 
Stress is a condition where a
person experiences tension due to
conditions that affect him. These conditions can be obtained from within a person or from an environment outside a person. Job stress can be interpreted as the pressure felt by employees because their work duties cannot be fulfilled. That is, stress arises when employees are unable to fulfill what is demanded by work (Ratna, 2007). Therefore, the level of pressure experienced by individuals is so high that the response to stress experienced is below normal. The factors that cause stress in work are the demands of work, physical demands, demands for roles or functions, and interpersonal demands (Ernie and Kurniawan, 2005). If someone has been placed in a particular job, he must feel himself recognized, he must feel satisfied with the work atmosphere and climate of the organization and feel that he has good opportunities for the future of his life.

The problem of work stress in organizations both private companies and government agencies is an important symptom observed since the emergence of demands for efficiency in work. Employee work stress needs to be managed by a company leader so that potentials that harm the company can be overcome. As a result of work stress, namely someone or employee becomes nerveous, feeling chronic anxiety, increasing tension in emotions, berifikir process and individual physical condition. According to Schuler, stress is a dynamic condition where individuals are faced with opportunities, obstacles and desires and the results obtained are very important but cannot be ascertained (Robbins, 2003).

Organizations in this case government agencies must pay attention to the work stress of employees, considering that employees are valuable assets for agencies that are important factors to achieve the goals of an organization. In relation to work, every individual must have experienced stress. Sometimes the stress experienced by a person is small and almost meaningless, but for others it is considered very disturbing and continues for a relatively long time. Job stress can have a positive and negative impact on individuals and for organizations or companies. Stress is said to be positive and is an opportunity if stress motivates employees to improve their performance in order to obtain maximum results. Stress is said to be negative if stress results in a decrease in employee productivity.

Organizational efforts are very closely related to the field of work occupied by an employee. Therefore, work placements are in accordance with their abilities, specify goals and anticipate obstacles, improve organizational communication effectively to form the same perceptions of job objectives, avoid uncertainty of roles, create a healthy work climate, restructure the position/job, and training/upgrading Professional development is a constructive effort to minimize the occurrence of work stress.

In general, a government agency or organization is influenced by environmental factors, both the internal environment and the external environment. 
Internal environment, namely the environment originating from within the organization itself, such as HR. While the external environment is an environment that comes from outside the organization, such as politics, economics, culture, and social. For this reason, Gorontalo District Health Office, which is the location where this research was conducted as one of the government agencies in the health sector, must be able to control both of these factors so that the agency's goals can be achieved.

The Gorontalo District Health Office, which is located in Limboto District, Gorontalo Regency, Gorontalo Province, is a regional government agency with a wide area of division of labor covering all Puskesmas located in 19 subdistricts. In this institution, researchers see that the level of stress experienced by employees is quite high. This assumption does not appear just like that, but is based on complaints raised by employees who were interviewed by researchers. Data from interviews and observations obtained by researchers show that almost all working conditions can cause stress depending on employee reactions. For example, an employee will easily receive and learn new work procedures, while another employee does not even reject it. However, there are a number of work conditions that often cause job stress for employees. Employees say that they often feel stressed because they are placed in a work location that is far from where they live. Conversely, employees whose workplaces are close to where they live feel normal stress levels. This also coincides with the level of comfort of employees and individuals in the position before being transferred.

As explained earlier that work stress factors are influenced by several factors including such as environmental uncertainties that affect the design of an organization's structure, this uncertainty also influences stress among employees in the organization. Political uncertainty also tends to result in stress for employees. Technology uncertainty is the third type that can cause stress. Because new innovations can make the skills and experience of an employee lagging behind in a very short period of time, computers, automation and other varieties of technological innovation pose a threat to many people and cause them stress.

From an organization's point of view, managerial parties may not care if employees experience low to moderate stress levels. The reason is that such a level can be functional which leads to higher employee performance. But high stress levels or even low but prolonged stress levels can make employees depressed, unmotivated and frustrated, so that in turn will cause employees unable to work optimally and work performance is affected. In a longer period of time, if the employee is unable to withstand work stress, he or she is no longer able to work in the company. At such a severe stage, stress can make employees fall ill so they are unable to enter work, or even employees must actively resign. These things encourage employee performance to 
decline and therefore demand action from the management. Steps that can be taken by the leadership and / or organization, namely transfer, promotion and demotion to improve employee performance and on the other hand can reduce individual work stress in this case employees. Basically mutations include the employee development process, because the purpose is to improve the efficiency and effectiveness of work within an agency. Because with the right transfer of position, employees will be motivated to increase the quantity and quality of work as well as a challenge for them so that effectiveness in work can be achieved and can reduce stress in a job.

\section{METHOD}

This research uses quantitative methods with survey techniques in the process of collecting data. The study was conducted at the Gorontalo District Health Office by using a sample of 74 respondents, which was the total population where respondents were all ASN employees registered at the Gorontalo District Health Office and spread throughout the relevant health agencies in Gorontalo Regency. The sample was selected using a random sampling technique.

\section{RESULTS AND DISCUSSION}

The researcher tested the hypothesis by comparing the tcount with the ttable at the significance level $(\alpha)=5 \%$ or 0.05 . The ttable value of the coefficients from the regression analysis can be summarized by a two-sided test and the degree of freedom (df) $74=1,665$. Comparison between $t$ count and $t$ table of regression coefficients can be seen in table 1

below:

Table 1 Comparison of tcounts with table of regression coefficients

\begin{tabular}{|c|c|c|c|}
\hline $\begin{array}{c}\text { Koefisien } \\
\text { Regresi }\end{array}$ & $\mathrm{t}_{\text {hitung }}$ & $\mathrm{t}_{\text {tabel }}$ & Sig \\
\hline 1 & 6.095 & 1.665 & 0.000 \\
\hline
\end{tabular}

Source: Primary Data Processed (2017)

From the table above, it is known that the value of tcount $\mathrm{x}$ is greater than the value of $t$ table that is $6,095>1,665$, thus $\mathrm{Ha}$ is accepted and $\mathrm{HO}$ is rejected. So the researchers concluded that there was a significant effect between work mutations on work stress.

To find out how much influence given mutations on work stress can be seen in the following summary model table: 
Table 2. Model Summary

\begin{tabular}{|l|r|r|r|r|}
\hline Model & R & \multicolumn{1}{|c|}{ R Square } & Adjusted R Square & $\begin{array}{c}\text { Std. Error of the } \\
\text { Estimate }\end{array}$ \\
\hline 1 & $.583^{\mathrm{a}}$ & .340 & .331 & 2.622 \\
\hline
\end{tabular}

a. Predictors: (Constant), Mutasi

b. Dependent Variable: Stres Kerja

Source: Primary Data Processed (2017)

The magnitude of the effect of variable $\mathrm{X}$ on variable $\mathrm{Y}$ can be known by looking at the $\mathrm{R}$ Square column in table 4.10. The value of 0.340 indicates that the effect of mutation on employee stress is 0.340 or if it is $34 \%$. While the remaining $66 \%$ is influenced by other variables not described in this study. The other variables in question are such as leadership style, organizational culture, climate, and work environment.

The problem of work stress in organizations both private companies and government agencies is an important symptom observed since the emergence of demands for efficiency in work. Employee work stress needs to be managed by a company leader so that potentials that harm the company can be overcome. As a result of work stress, namely someone or employee becomes nerveous, feeling chronic anxiety, increasing tension in emotions, berifikir process and individual physical condition.

Job stress can have a positive and negative impact on individuals and for organizations or companies. Stress is said to be positive and is an opportunity if stress motivates employees to improve their performance in order to obtain maximum results. Stress is said to be negative if stress results in a decrease in employee productivity. Therefore, work placements are in accordance with their abilities, specify goals and anticipate obstacles, improve organizational communication effectively to form the same perceptions of job objectives, avoid uncertainty of roles, create a healthy work climate, restructure the position/job, and training/upgrading Professional development is a constructive effort to minimize the occurrence of work stress.

Data from interviews and observations obtained by researchers show that almost all working conditions can cause stress depending on employee reactions. For example, an employee will easily receive and learn new work procedures, while another employee does not even reject it. However, there are a number of work conditions that often cause job stress for employees. Employees say that they often feel stressed because they are placed in a work location that is far from where they live. Conversely, employees whose workplaces are close to where they live feel normal stress levels. 
This also coincides with the level of comfort of employees and individuals in the position before being transferred.

Basically mutations include the employee development process, because the purpose is to improve the efficiency and effectiveness of work within an agency. Because with the right transfer of position, employees will be motivated to increase the quantity and quality of work as well as a challenge for them so that effectiveness in work can be achieved and can reduce stress in a job.

However, the problem today is how the employee paradigm regarding the mutation itself. Mutations that should have been motivated turned out to be a scourge for employees who entered the list of mutations. Of course this is because the implementation of the mutations that have occurred so far have not referred to the HRM principles, where mutations are carried out in addition to fulfilling the shortage of staff in other units / sections as well as to place employees in accordance with their skills, abilities and fields. Current mutations are political products that are implemented and targeted at individuals who are not considered part of political promises. So, instead of minimizing stress, on the contrary it actually adds to work stress. Referring to the results of the study, the effect of mutations on work stress can have a positive impact during its implementation in accordance with the indicators that exist in the mutation itself. Positive influence based on the findings of the statistical analysis shows that the better the application of employee mutations, the greater the opportunity to minimize the occurrence of job stress on employees.

\section{CONCLUSION}

Based on the results and discussion, the conclusions that can be drawn by researchers in this study are:

1. Job mutations affect employee job stress. To minimize the occurrence of work stress on employees at the Gorontalo District Health Office, it is worth trying to do work mutations. The new work and task environment can help employees to relieve stress with notes in accordance with what the employees want without ignoring the interests of the agency.

2. Mutations have a positive effect on employee work stress. The positive influence in question is the better the application of mutations to employees, the better will be the stress management of employees. As long as the mutation is carried out in accordance with HRM principles, work stress will not occur. Mutations must be a motivation for employees, not the other way around, it is a scourge for employees.

\section{REFERENCES}

Alma, Buchari. 2009. Pengantar Bisnis.

Bandung. Alfabeta

Anoraga, Pandji. 2007. Pengantar Bisnis. Jakarta. Rineka Cipta

Arikunto, Suharsimi. 2001. Metode Penelitian. Gramedia. Jakarta. 
Budi, Sutedjo Darma Oetomo. 2006. Perencanaan dan Pembangunan Sistem Informasi. Yogyakarta. Andi Offset

Dodi, Hendri dan Evanita Susi. 2014. Pengaruh Mutasi, Kompensasi Dan Motivasi Terhadap Kepuasan Kerja Karyawan Di PT. PLN (PERSERO) Wilayah Sumatera Barat Area Solok. Padang. Fakultas Ekonomi Universitas Negeri Padang

Ernie dan Kurniawan. 2005. Pengantar Manajemen. Jakarta. Prenada Media Group

Fathoni, Abdurrahman. 2006. Manajemen Sumber Daya Manusia. Jakarta. PT. Rineka Cipta

Ghozali, Imam. 2001. Analisis Multivariate dengan Program SPSS. Semarang. Badan Penerbit Universitas Diponegoro.

Ghozali, Imam. 2005. Aplikasi Analisis Multivariate dengan SPSS. Semarang. Badan Penerbit UNDIP.

Handoko, T Hani. 2008. Manajemen Personalia Sumber Daya Manusia. Edisi 2. Yogyakarta. BPFE

Hariandja, Marihot Tua Efendi. 2007. Manajemen Sumber Daya Manusia: Pengadaan, Pengembangan, Pengkompensasian, dan Peningkatan Produktivitas Pegawai. Jakarta: Grasindo

Hasibuan, Malayu S.P. 2003. Manajemen Sumber Daya Manusia. Jakarta. Bumi Aksara
Henry Simamora. 2004. Manajemen Sumber Daya Manusia. Edisi Ke-3. STIE YKPN. Yogyakarta.

Luthans, F. 2000. Perilaku Organisasi. Yogyakarta. Andi

Mangkunegara, Anwar Prabu. 2005. Sumber Daya Manusia perusahaan. Remaja Rosdakarya: Bandung

Moh. Nazir. 2000, Metode Penelitian, Cetakan Kesatu, Jakarta, Ghalia Indonesia.

Robbins, Stephen P. 2003. Perilaku Organisasi. Jakarta. Index

Rochmanasari, Dina dan Mudiantono, Mudiantono. 2013. Analisis Pengaruh Stres Kerja Dan Gaya Kepemimpinan Terhadap Kinerja Pegawai Perusahaan Daerah Bank Perkreditan Rakyat Bkk Kabupaten Demak.Semarang. Fakultas Ekonomi Undip.

Sadili, Samsudin. 2006. Manajemen Sumber Daya Manusia. Jakarta. Pustaka Setia

Sastrohadiwiryo, Siswanto B. 2003. Manajemen Tenaga Kerja Indonesia. Jakarta. Bumi Aksara

Saydam, Gouzali. 2000. Manajemen Sumber Daya Manusia (Human Resource) Suatu Pendekatan Mikro, Djanbatan, Jakarta

Septianto, Dwi. 2010. Pengaruh Lingkungan Kerja Dan Stres Kerja Terhadap Kinerja Karyawan Studi Pada PT. Pataya Raya Semarang. 